\title{
Communities of Berteroa incana in Europe and their geographical differentiation*,**,***
}

L. Mucina' \& D. Brandes²

${ }^{1}$ Department of Geobotany, Institute of Experimental Biology and Ecology, Slovak Academy of Sciences, Sienkiewiczova 1, 81434 Bratislava, Czechoslovakia

${ }^{2}$ University Library of the Technical University, Pockelsstrasse 13, D-3300 Braunschweig, F.R.G

Keywords: Berteroetum incanae, Dauco-Melilotion, Europe, Geographical race, Onopordetalia, Synchorology, Syntaxonomy

\begin{abstract}
Two geographical races have been established within the Berteroetum incanae in Europe. The Galium mollugo race of the Berteroetum incanae is characteristic of the western part of the distribution area of the association whereas the relevés from the eastern part of Europe are classified as the Acosta rhenana race of the Berteroetum incanae. Adventitious Berteroetum incanae from the Netherlands has been shown to be a separate subunit within the Galium mollugo race of the Berteroetum incanae.
\end{abstract}

\section{Introduction}

Berteroa incana is a biennial rosette herb producing a high number of viable seeds. It is a competitive ruderal (sensu Grime, 1979). Phytosociologically it is limited to the order Onopordetalia, and especially the alliance Dauco-Melilotion. Communities in which Berteroa occurs as a dominant are found in many parts of Europe, though not very frequently. In this paper attention will be focussed on the geographical differentiation of these communities.

* A number of phytosociological relevés has been used by courtesy of Th. Müller, Nürtingen, F. Runge, Münster, V. Westhoff, Nijmegen, H. Lienenbecker, Steinhagen, H. Passarge, Eberswalde, W. Nezadal, Erlangen, W. Kunick, Stuttgart, F. Grüll, Brno, I. Jarolímek and M. Zaliberová, both Bratislava. For valuable comments on the manuscript we are indebted to $V$. Westhoff, E. van der Maarel, R. Neuhäusl and J. J. Barkman. The English of an earlier version of the manuscript has been kindly corrected by $\mathrm{Mr}$ Henry Moreton.

** The nomenclature of species follows Tutin et al. (1964-1980) with some changes according to Smejkal (1980).

*** Acknowledgement. The work of the senior author was partly supported by the University of Nijmegen Research Fellowship in Biology 1980/1981.

\section{Material and methods}

From Austria, Bulgaria, Czechoslovakia, Denmark, Federal Republic of Germany, German Democratic Republic, The Netherlands, Federal Republic of Germany, Poland and Roumania 211 relevés of Berteroa incana communities have been collected and combined into local rather homotoneous tables. With the aid of a computer these have been arranged into a synoptic table, in which species occur with their constancy class values. In columns representing local tables with less than 5 relevés the species are indicated by their real presence values. Condensed local tables (constancy values only) have been added to the synoptic table afterwards.

Syntaxonomical handling was accomplished by traditional methods of the Braun-Blanquet approach (Braun-Blanquet, 1964; see also Westhoff \& van der Maarel, 1978). The columns in the table have been ordered from west to east in Europe. Centaureo diffusae-Berteroetum tables were added at the end of the synoptic table.

The numerical handling of the data includes numerical classification and ordination techniques. Ward's method (WM; Sum-of-squares clustering 
sensu Orlóci, 1967) and Complete linkage clustering (CLC; see Sneath \& Sokal, 1973 for details) have been adopted as numerical classification methods. The original abundance and cover values of the Braun-Blanquet scale have been transformed according to ordinal transformation of van der Maarel (1979). The computation was performed with the CLUSTAN 1C package of Wishart (1978). Euclidean distance (ED) with WM and Similarity ratio (SR) with CLC (see Wishart, 1.c. for further information) were used as resemblance functions. Reciprocal averaging (RA; Hill, 1973, program DECORANA, Hill, 1979) is the ordination technique used. Comparisons between classifications have been performed using Goodman-Kruskal coefficient of association (Goodman \& Kruskal, 1954) and the program GOODM (Goldstein \& Grigal, 1972).

\section{Results}

\section{Syntaxonomy}

On the basis of the Braun-Blanquet approach two associations were established within the ensemble of Berteroa incana communities (Table 1 see Appendix): Berteroetum incanae Sissingh et Tideman in Sissingh 50 and Centaureo diffusaeBerteroetum Oberdorfer 57.

Stands of the Berteroetum incanae are usually dominated by Berteroa incana, sometimes also by Acosta rhenana (in eastern Europe). They have two or three layers. Besides the dominating species also Plantago lanceolata, Reseda lutea, Silene alba, Echium vulgare and Lolium perenne form the upper herb sublayer. Some grasses reach as high as $1 \mathrm{~m}$ (Agropyron repens, Arrhenatherum elatius) and locally form another, third, rather loose sublayer. Some other tall herb species are found either in a vegetative stage (rosette) of the specimens of lower vitality. The lowermost sublayer is composed of dwarf or procumbent herbs as Medicago lupulina, Alyssum alyssoides, Sedum sexangulare and Arenaria serpyllifolia. In some place also a moss layer is found, usually including Bryum argenteum, Brachythecium albicans, Hypnum vaucheri and Rhacomitrium canescens.

The Berteroetum incanae colonizes well-drained, warm sandy to loamy (loess) soils of moderate nitrogen supply. The community occurs in very spe- cial habitats in the western part of its area, where it is restricted to docks and railway stations and more or less dependent on the steady supply of adventitious species. Originally, the community was described from tips near corn-mills in the south and southeast Netherlands. Recently it started spreading here along roads on sandy soils. On sandy soils it also occurs in Lower Saxony, the northern part of Franconia, Brandenburg and Mecklenburg. The habitats of the Berteroetum incanae in eastern Europe are more diverse. They are most frequently found on moderately alkalic soils along roads, on abandoned places of various origin, very often on loess slopes and river dykes or in limestone quarries (Mucina, 1981b).

Berteroa incana is considered the only characterspecies of the association Berteroetum incanae, with its optimum fidelity in western Europe. Though not dominant, Berteroa incana is quite common in other Dauco-Melilotion and Onopordion communities in eastern Europe (e.g. Gutte, 1972; Gutte \& Hilbig, 1975; Kępczyński, 1975; Czaplewska, 1980; Mucina, 1981a, b).

According to the geographical variation the community can be divided into two subunits. The Galium mollugo race is characteristic of the northwestern part of the area (The Netherlands, Denmark, northern and western parts of F.R.G., a part of East Germany). Holcus lanatus, Cerastium arvense, Carduus nutans, Lamium album, Senecio vulgaris etc. are differentials for the unit.

The Acosta rhenana race, from Czechoslovakia, Poland, Hungary and the Balkans, is differentiated by a large number of species, particularly of (sub)continental distribution (Table 1), many of which are shared with the Centaureo-Berteroetum.

Since all differential species except Cichorium intybus and Crepis rhoeadifolia have their sociological optimum in other syntaxa than in the Dauco-Melilotion alliance, the units discussed here are not considered as regional associations, but as geographical races (sensu Oberdorfer, 1957, 1968; Werger \& van Gils, 1976; Westhoff \& van der Maarel, 1978).

In western Europe the Berteroetum incanae occurs in contact with Arrhenatheretalia communities, whereas in eastern Europe it is more frequently found in contact with the Festuco-Brometea and Sedo-Scleranthetea (Festucetalia valesiacae and Sedo-Scleranthetalia). 
As a rule the dominant species of the Centaureo diffusae-Berteroetum is Acosta diffusa (= Centaurea diffusa), Berteroa incana being a sub-dominant. The stands of the community are rather large in size (Oberdorfer, 1957), and rather open (50\% average cover (Seybold \& Müller, 1972).

The community occurs in particular along railways and at railway yards, on well-drained sandy soils with high amounts of ash and dross (Gutte \& Hilbig, 1975; Sowa, 1975). As the sites are exposed to direct sun irradiation, the temperature of the substratum can become rather high. This favours not only the dominance of $A$ costa diffusa, but also the occurrence of other adventitious species as $L i$ naria genistifolia, Psyllium scabrum, Salsola kali subsp. ruthenica as was observed in West and East Germany (Oberdorfer, 1957; Gutte \& Hilbig, 1975). All these species are known to be thermophilous. The community as a whole seems to be adventitious throughout its distribution area.

Synecologically, the community is related to the group of communities dominated by Salsola kali ssp. ruthenica, Psyllium scabrum and Corispermum species. According to Oberdorfer (1957) there are syndynamical relations between the Centaureo diffusae-Berteroetum and the Festuco-Sedetalia and Festuco-Brometea. The Centaureo diffusaeBerteroetum is documented from West Germany, West Berlin, East Germany and Poland (see Appendix). Acosta diffusa is a regional character-species of the association. Differential species against the Berteroetum incanae include Psyllium scabrum, Lepidium densiflorum, Oenothera parviflo$r a$ and Herniaria glabra. The segregation is strengthened by the absense of differential species against the Berteroetum incanae (Silene alba, Dactylis glomerata, Urtica dioica etc.). This group is largely composed of nitrophilous and mesophilous species, mostly of Arrhenatheretalia and Sisymbrietalia.

\section{Cluster analyses}

The first cluster dichotomy of WM (Fig. 1) splits the Dutch relevés of Sissingh (1950) and the rest of the material. Phytosociologically cluster $H$ represents the Berteroetum incanae releves on which the original description of the syntaxon has been based. The second dichotomy yields two clusters: D and B.

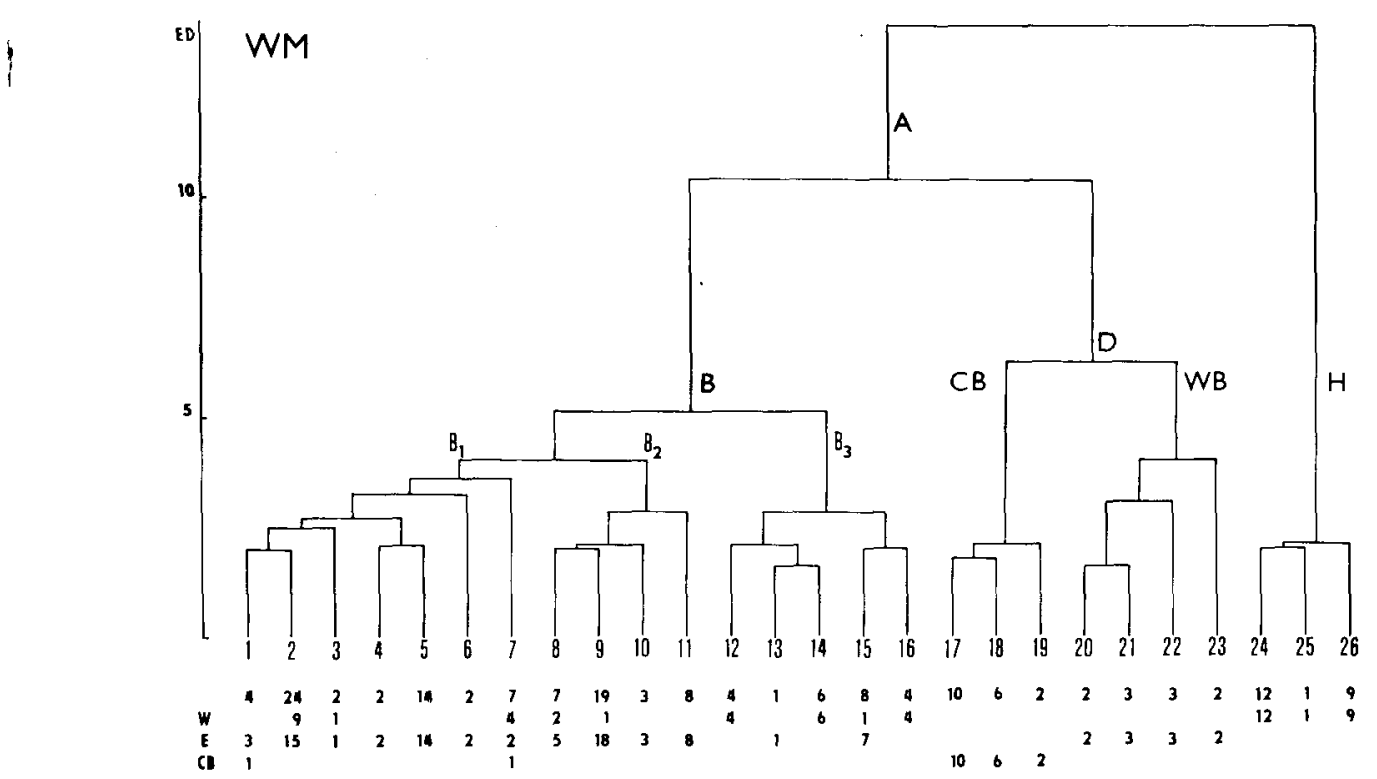

Fig. 1. Dendrogram of Ward's clustering method. Only the upper part of the hierarchy is shown (starting with 26 clusters). The numerals below the dendrogram indicate: total number of relevés, No. of the western race relevés, No. of the eastern race relevés, No. of the Centature-Berteroetum relevés in a starting cluster resp. B - the mixed cluster of the eastern and western race records; $\mathrm{CB}$ - the Centaureo-Berteroetum cluster; WB - the cluster of intermediate local tables (Berlin, Bavaria, etc.); $\mathbf{H}$ - the cluster of records from The Netherlands. 
The former one is composed of two subclusters, viz. $\mathrm{CB}$ and WB. The cluster CB is entirely composed of the Centaureo diffusae-Berteroetum relevés. It comprises $90 \%$ of all Centaureo-Berteroetum relevés analyzed. The dendrogram branch 17 represents the Centaureo-Berteroetum from a part of Poland (the district of Lublin and the surroundings of Łodz), the others within the cluster CB are composed of relevés coming from Wroctaw (Poland), West Berlin and southern F.R.G. The cluster WB comprises two local tables of the Berteroetum incanae s.str., namely those from West Berlin (the branches 20, 21; Fig. 1) and Bavaria (the branches 22, 23; Fig. 1). These correspond to the columns 14 and 11 of Table 1 resp. The tables come from the region where the two races of the Berteroetum in- canae co-occur. Nevertheless, according to the overall floristic composition these local tables have been placed into the eastern race of the Berteroetum incanae.

The largest cluster $\mathbf{B}$ is a mixture of relevés of both Berteroetum incanae races. From the phytosociological point of view a somewhat clearer pattern arises on the level of the subclusters $B_{1}, B_{2}$ and $B_{3}$ within $B$. Cluster $B_{1}$, although composed mostly of the eastern race relevés, remains heterogeneous. Cluster $B_{2}$ is homogeneous. Cluster $B_{3}$ is also homogeneous.

The pattern in the WM dendrogram on the 4cluster level, reasonably corresponds to that of the CLC (Fig. 1 and 2, Table 2).

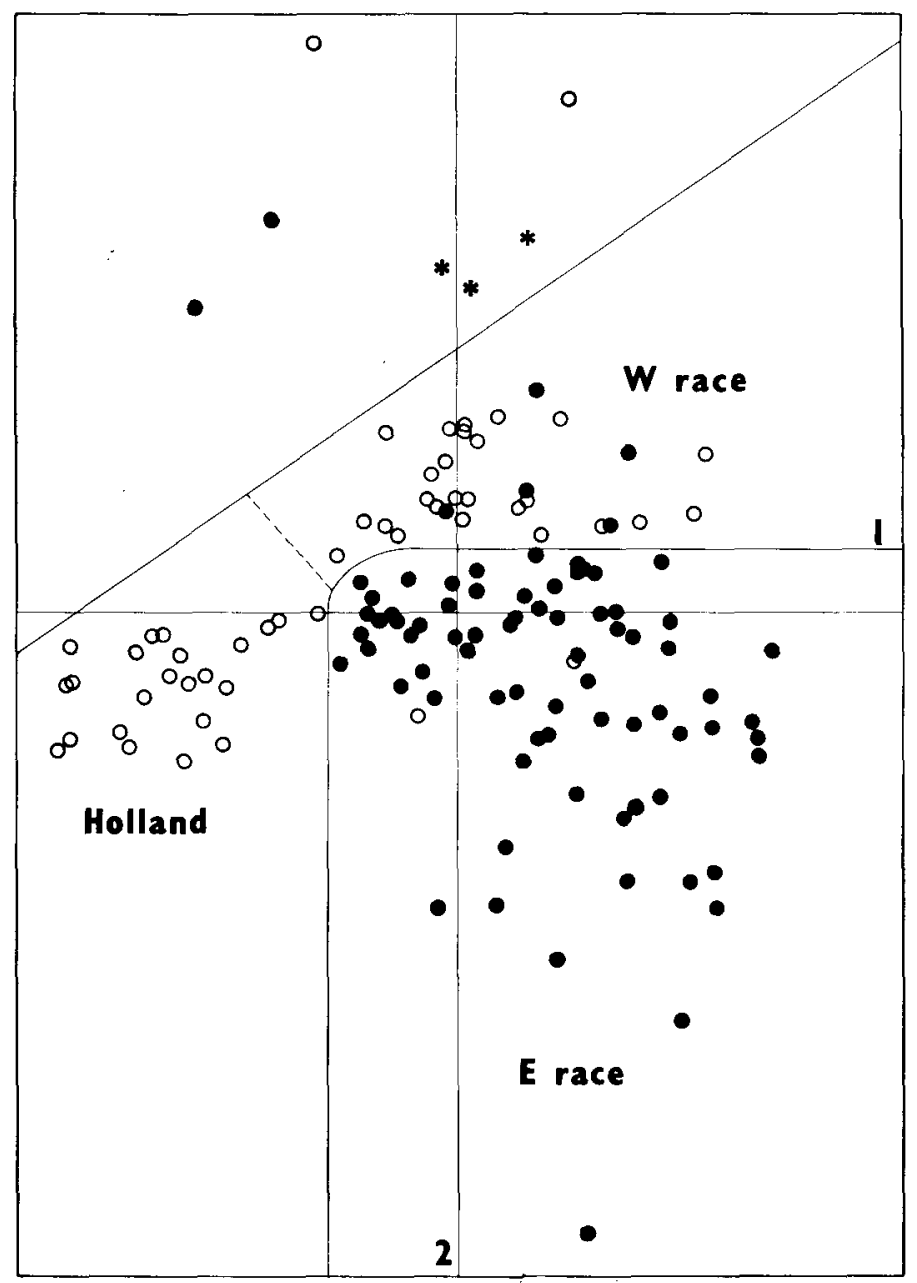

Fig. 2. Reciprocal averaging ordination plane (1 st/2nd axes). Full circles - E race; empty circles - W race; asterisks - Centaureo-Berteroetum. 
Table 2. Goodman-K ruskal comparisons of classifications of the Berteroa incana communities

\begin{tabular}{llll} 
& 1 & 2 & 3 \\
\hline 1 Syntaxonomical classification & $\mathrm{x}$ & 0.395 & 0.400 \\
2 Complete linkage clustering & & $\mathrm{x}$ & $\begin{array}{l}0.727 \\
\text { 3 Ward's method }\end{array}$ \\
\hline
\end{tabular}

\section{Ordination}

An ordination of the total data set produced a typical horseshoe on the ordination plane of axes 1 and 2 . The bulk of relevés have been concentrated around the joining of the two wings of the horseshoe. The wings themselves include outlying Cen-
taureo-Berteroetum respectively of Acosta rhenana-dominated relevés. After removing the outliers the subsequent ordination revealed a much clearer pattern. Some of the Centaureo-Berteroetum relevés are outliers being scattered along the positive side of axis 2. The geographical races of the Berteroetum incanae are separated along a diagonal (Fig. 3). The relevés from The Netherlands are separated from the Acosta rhenana race along axis 1 . The remainder of the western material is more or less separated from the eastern one along axis 2 . There is an overlap between the races along axis 2, which corresponds to the existence of mixed clusters, as depicted in Figures 1 and 2.

The data used for the numerical analyses are scattered throughout central Europe approximate-

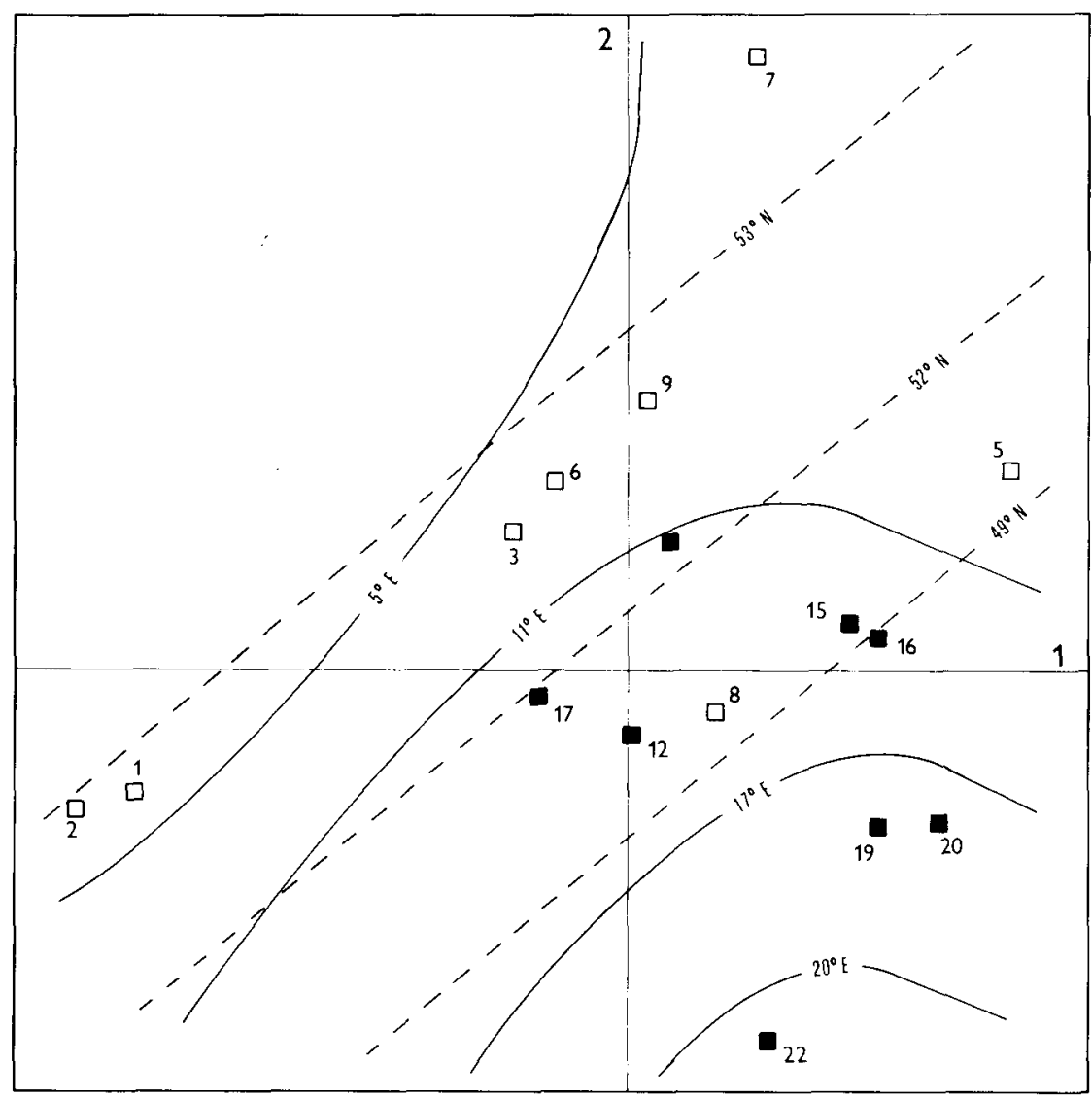

Fig. 3. Reciprocal averaging ordination of the Berteroetum incanae local tables. The cent roids of the local tables are plotted. The solid and dashed lines represent geographical longitude and latitude resp. Full squares - E race; empty squares - W race; 1, 2 - the Netherlands; 3 - Westfalen; 5-Karlsruhe; 6 - Bielefeld; 7 - Bremen; 8 - Maindreieck near Ochsenfurt; 9 - Braunschweig; 10 - Hagenow, Schwanenbeck-Alpenberge, Berlin; 12 - Bamberg, Redniztal in Bavaria; 15 - Brno; 16 - Niederösterreich, Burgenland; 17 - Bydgoszcz; 19 - western Slovakia; 20 - Bratislava; 22 - the Východoslovenská Nížina Lowland. 


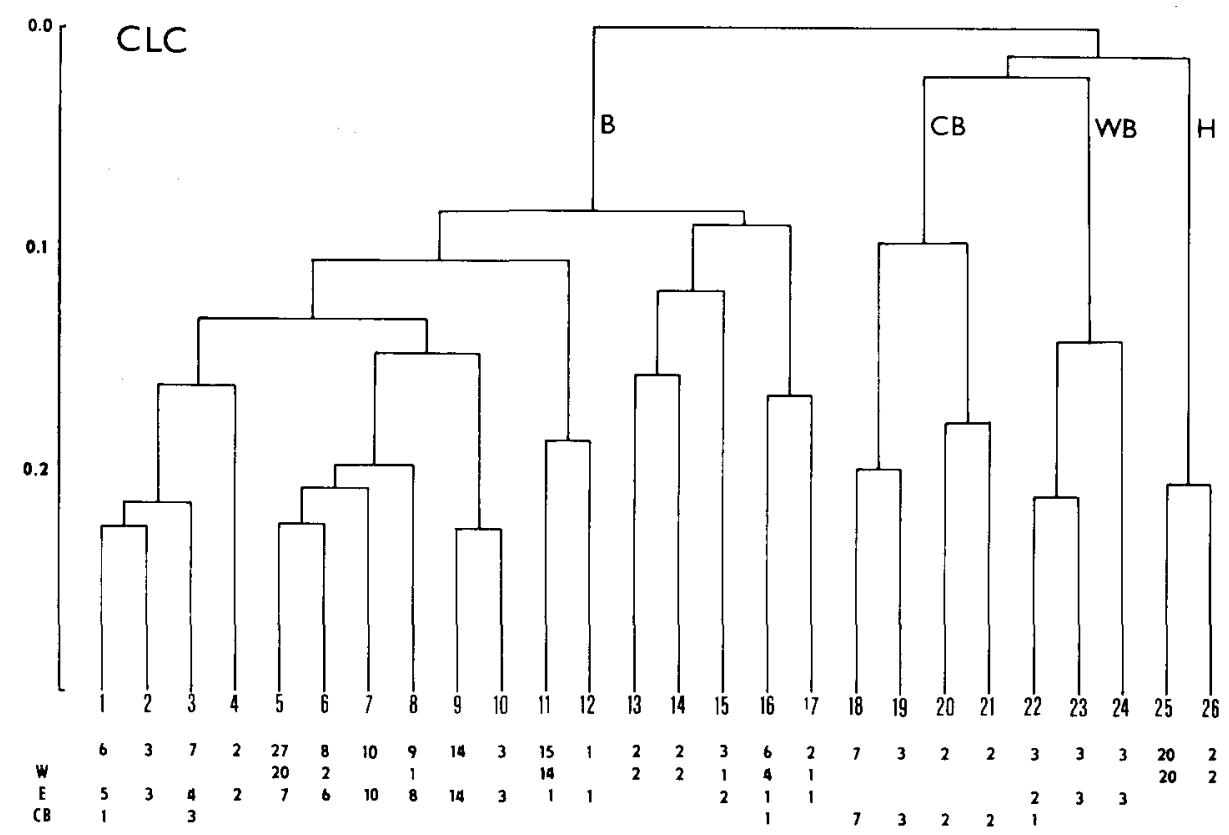

Fig. 4. Dendrogram of complete linkage clustering. For further explanation see Figure 1.

ly within the range $53^{\circ} \mathrm{N}$ to $48^{\circ} \mathrm{N}$ and $5^{\circ} \mathrm{E}$ to $22^{\circ} \mathrm{E}$. It might seem that the area of the Berteroetum incanae in Europe is much larger in west-east direction than in the south-north one, but the community is also reported from Bulgaria (Table 1 , column 24) and Sweden (Olsson, 1978).

The values for $\mathrm{N}$ latitude and $\mathrm{E}$ longitude for the local tables of the Berteroetum incanae s. str. show a diagonal isoline pattern (Fig. 4). The tables from Bavaria, Brandenburg, the surroundings of Braunschweig and Berlin (Table 1, columns 8-14) are considered 'transitional' as they are found where the races meet (Fig. 4). The distribution of the Berteroetum incanae in Europe is not continuous although the two races are not separated by a gap. There is a transitional zone between $10^{\circ}$ to $13^{\circ} \mathrm{E}$ and $49^{\circ}$ to $52^{\circ} \mathrm{N}$ where representatives of the races co-occur.

If we compare the RA-diagram with the WM dendrogram we find that the first WM dichotomy corresponds to the segregation of the clusters along axis 1 , and the second one to the segregation along axis 2 (cf. Figs. $1 \& 3$ ).

\section{Discussion}

There are two general opinions concerning the width of the Berteroetum incanae as a syntaxon. A 'narrow' concept is promoted by Westhoff $\&$ den Held (1975), Passarge (1964), Pop \& Hodişan (1970) and to some extent also Soó (1973) and Mucina (1981b). In this conception the MelandrioBerteroetum (a synonym of the Berteroetum incanae), Verbasco-Berteroetum Passarge 1957, Centaureo diffusae-Berteroetum, and some times also the Rorippo pyrenaicae-Berteroetum Pop et Hodişan form a group of vicarious associations (Passarge, 1964) or better: an association group (sensu Westhoff \& van der Maarel, 1978). Seybold \& Müller (1972) representing a 'broad' concept include not only the Verbasco-Berteroetum and Centaureo-Berteroetum, but also the Verbasco-Chondrilletum Tillich 1969 into the Berteroetum incanae s. 1. Our current opinion is intermediate to the extent that we regard the Centaureo-Berteroetum as a separate association. This distinction is kept also by German and Czechoslovakian authors (Oberdorfer et al., 1967; Oberdorfer \& Müller, 1979; Hejný et al., 1979). Most of the CentaureoBerteroetum relevés come from Poland. This might 
be a reason why traditionally the releves of the Berteroetum incanae s.str. are classified under the Centaureo-Berteroetum (Kępczyński, 1975; Czaplewska, 1980). The Verbasco-Berteroetum and Rorippo-Berteroetum could not be recognized in the synoptic table as separate associations, thus they were included into the list of synonyms of the Berteroetum incanae s.str. The Melandrio-Berteroetum and Verbasco-Berteroetum associations are included into the western race of the Berteroetum incanae, whereas the Rorippo-Berteroetum association is placed within the eastern race of the Berteroetum incanae. The Cynoglosso-Berteroetum (Olsson, 1978) from southern Sweden could not be included in the synthesis because a different sampling technique was used. Because of the lack of relevés from Hungary and the Balkan Peninsula we could not confirm the Centaureo micranthae-Berteroetum (Ubrizsy, 1955; see also Soó, 1971; Mititelu \& Barabaş, 1972) as a regional association. Ubrizsy in Soó(1971) mentioned Cephalaria transsilvanica as a character-species of the latter unit. The one relevé from Bulgaria (Table 1, column 24) contains a number of submediterranean species. A reconsideration of the syntaxonomy of the Berteroa incana-dominated communities in Bulgaria may be appropriate if more material is available (see also Mucina, 1979).

Since the first descriptions (Westhoff et al., 1946; Sissingh, 1950; Lebrun et al., 1949; Oberdorfer, 1957), as early as 1966, (Ubrizsy, 1955; Passarge, 1964; Soó, 1964; Gutte, 1966) the Berteroa incana communities have been assigned to the Onopordion acanthii. Later, after Görs (1966) had described the Dauco-Melilotion, German and Czechoslovakian authors considered them as members of this newly described alliance (Seybold \& Müller, 1972; Oberdorfer et al., 1967; Oberdorfer \& Müller, 1979; Hejný et al., 1979; Gutte, 1972; Gutte \& Hilbig, 1975; Mucina, 1981b). Only Westhoff \& den Held (1975), and Polish, Roumanian and Hungarian authors still hold to the idea of the Onopordion acanthii as being the higher syntax on of the Berteroetum incanae (cf. Pop \& Hodişan, 1970;

- Fijałkowski, 1971; Mititelu \& Barabas, 1971, 1972; Rostański \& Gutte, 1971, Kępczyński, 1975; Czaplewska, 1980). Until now the Dauco-Melilotion has not frequently been used in Poland, Hungary and Roumania. The description of a separate alliance Berteroion incanae by Radke (1979) is not supported by data.
The lower-ranked syntaxa described within the Berteroetum incanae s.str., namely the Berteroetum incanae medicaginetosum and typicum of Sissingh (1950), the Berteroetum incanae, typical variant, and the variant with Salvia nemorosa of Mucina (1981b) and the Berteroetum incanae rorippetosum pyrenaicae of Pop \& Hodişan (1970), seem to be of very local importance. Like the race of Salsola kali of the Centaureo-Berteroetum (Gutte, 1972) they do not represent separate units in the synoptic tables.

Comparing both races of the Berteroetum incanae in terms of species diversity one recognizes a more general pattern, with a higher species diversity and higher number of plant associations per alliance towards southeastern Europe. This has also been noted within the Malvion neglectae and Onopordion acanthii (cf. Mucina, 1979, 1981a). This holds also for natural vegetation types, e.g. when comparing (sub)alpine chalk grasslands or beech woods of central Europe to those of the Balkan (see Neuhäusl in Dierschke, 1981). The causes of this phenomenon have not been appropriately evaluated yet. One could look for causes in dramatical florogenetical processes during Pleistocene glaciation which, gave origin to various floral refugia in eastern Europe, and to diversification centra of species. Diverse flora migration routes in the Holocene and a lower intensity of human impact upon the landscape in eastern Europe as well as a diversity of stands may also be considered.

A question may arise while inspecting the dendrograms why the first dichotomy does not correspond to the division into the Berteroetum incanae and Centaureo-Berteroetum. The Centaureo-Berteroetum appeared closer to the eastern race of the Berteroetum incanae and seemed to be rather a subunit of the eastern race than a separate association. Nevertheless, the Centaureo-Berteroetum is considered an association due to the high fidelity value of Acosta diffusa. The species, however, is weighted by SR the same way as any other discriminant character. Although there are many good discriminant characters (differential species) between the Berteroetum incanae and CentaureoBerteroetum, the eastern race of the Berteroetum incanae and Centaureo-Berteroetum, have a lot of species in common, since the distribution areas of both phytocoena are largely the same.

The comparisons between the results of the numerical and syntax onomical classifications, respec- 
tively (Table 2), yield rather low resemblance values. The differences might be explained by (1) differing classification criteria adopted in both approaches, the weighting of certain species (see the preceding paragraph), and (2) by the fact that the numerical classifications are based on relevés whereas the syntaxonomical treatment is based upon local tables.

\section{References}

Brandes, D., 1977. Die Onopordion-Gesellschaften der Umgebung Braunschweigs. Mitt. Florist.-Soziol. Arbeitsgem., N.F. 19/20: 103-113.

Braun-Blanquet, J., 1964. Pflanzensoziologie. Grundzüge der Vegetationskunde. 3. Aufl. Springer, Wien, New York. 865 pp.

Czaplewska, J., 1980. Zbiorowiska roślin ruđeralnych na terenie Aleksandrowa Kujawskiego, Ciechocinka, Nieszawy i W rocławka. Stud. Soc. Sci. Torunensis, Sect. Bot. 11: 1-76.

Dierschke, H., 1981. Zur syntaxonomischen Bewertung schwach gekennzeichneter Pflanzengesellschaften. In: H. Dierschke (ed.). Syntaxonomie, Ber. Int. Symp. Int. Ver. Vegetkde., pp. 109-122. J. Cramer, Vaduz.

Fijałkowski, D., 1971. Zbiorowiska synantropijne wyrobisk krędowych w Chelmie i Rejowcu na Lubelszczyznie. Mater. Zakł. Fitosoc. Stosow. Uniw. Warszaw. 27: 273-289.

Fijałkowski, D., 1978. Synantropy roślinne Lubelszczyny. Lubel. Tow. Nauk., Prace Wydz. Biol. 5: 1-260.

Goldstein, R.\& Grigal, D. F., 1972. Computer programs for the ordination and classification of ecosystems. Ecol. Sci. Div. Publ., Oak Ridge National Laboratory, $417 \mathrm{pp}$.

Goodman, L. A. \& Kruskal, W. H., 1954. Measures of association for cross classifications. J. Am. Stat. Ass, 49: 732-764.

Grüll, F., 1982. Málo známá pionýrská společenstva rostlin na obnažených půdách stavenišs' mèsta Brna. Preslia 54: $149-166$.

Gutte, P., 1966. Die Verbreitung einiger Ruderalpflanzengesellschaften in weiteren Umgebung von Leipzig. Wiss. Z. Univ. Halle, Ser. Math.-Nat. 15: 937-1010.

Gutte, P., 1972. Ruderalpflanzengesellschaften West- und Mittelsachsens. Feddes Repert. 83: 11-122.

Gutte, P.\& Hilbig, W., 1975. Ubersicht über die Pflanzengesellschaften des südlichen Teiles der DDR. XI. Ruderalgesellschaften. Hercynia N.F. 12: 1-30.

Hejný, S., Kopecký, K., Jehlík, V. \& Krippelová, T., 1979. Prrehled ruderálních rostlinných společenstev Ceskoslovenska. Rozpr. Čs. Akad. Věd., Ser. Math. Nat. 89/2: 1-100.

Hill, M. O., 1973. Reciprocal averaging: An eigenvector method of ordination. J. Ecol. 61: 237-249.

Hill, M. O., 1979. DECORANA. A Fortran program for detrended correspondence analysis and reciprocal averaging. Ecology and Systematics, Cornell University, Ithaca. iii +52 pp.

Hülbusch, K. H. \& Kuhbier, H., 1979. Zur Soziologie von Senecio inaequidens DC. Abh. Naturw. Verein Bremen 39: 47-54.
Kępczyński, K., 1975. Zbiorowiska roślin synantropijnych na terenie miasta Bydgoszczy. Acta Univ. Nicolae Copernici, Ser. Biol. 17: 3-87.

Lebrun, J., Noirfalise, A.. Heinemann, P. \& Vanden Berghen, C., 1949. Les associations végétales de Belgique. Bull. Soc. Roy. Bot. Belg. 82: 105-199.

Lienenbecker, H., 1968. Die Graukressen-Gesellschaft (Berteroetum incanae) im östlichen Westfalen. Natur u. Heimat 28 : 126-127.

Maarel, E. van der, 1979. Transformation of cover-abundance values in phytosociology and its effects on community similarity. Vegetatio 39: 97 114.

Mititelu, D. \& Barabaş, N., 1971. Vegetaţia Văii Trotuşului (sectorul Urecheşti - Tg. Trotuş). Stud. Comunic. Bacãu: $79 \mathrm{l}-820$

Mititelu, D. \& Barabaş, N., 1972. Vegetaţia ruderală şi segetală din interiorul şi imprejurimile Municipiului Bacău. Stud. Comunic. Bacău: $127-148$.

Mucina, L., 1979. Synantropná vegetácia stredného Považia I. Spoločenstvá radu Onopordetalia. Thesis, Comenius University, Bratislava.

Mucina, L., 1981 a. Die Ruderalvegetation des nördlichen Teils der Donau-Tiefebene. 1. Onopordion acanthii-Verband. Folia Geobot. Phytotax. 16: 225-263.

Mucina, L., $198 \mathrm{lb}$. Die Ruderalvegetation des nördlichen Teils der Donau-Tiefebene. 2. Gesellschaften des Dauco-Melilotion-Verbandes auf ruderalen Standorten. Folia Geobot. Phytotax. 16: 347-389.

Oberdorfer, E., 1957. Süddeutsche Pflanzengesellschaften. Pflanzensoziologie 10: 1-564.

Oberdorfer, E., 1968. Assoziation, Gebietsassoziation, Geographische Rasse. In: R. Tüxen (ed.). Pflanzensoziologische Systematik. Ber. Int. Symp. Int. Ver. Vegetkde. Stolzenau/ Weser 1964, pp. 124-141. Junk, Den Haag.

Oberdorfer, E. et al., 1967. Systematische Ubersicht der westdeutschen Phanerogamen und Gefässkryptogamen-Gesellschaften. Schriftenrh. Vegetkde. 2: 7-62.

Oberdorfer, E. \& Müller, Th., 1979. Pflanzensoziologische Exkursionsflora. 4. Aufl. Eugen Ulmer, Stuttgart. 997 pp.

Olsson, H., 1978. Vegetation of artificial habitats in northern Malmö and environs. Vegetatio 36: 65-82.

Orlóci, L., 1967. An agglomerative method for classification of plant communities. J. Ecol. 55: $193 \cdot 205$.

Passarge, H., 1959. Pflanzengesellschaften zwischen Trebel, Grenzbach und Peene (O-Mecklenburg). Feddes Repert. 138: $1 \cdot 56$.

Passarge, H., 1964. Über Pflanzengesellschaften des Hagenower Landes. Arch. Nat. Meckl. 10: 31-51.

Pop, I. \& Hodişan, I., 1970. Studiu fitocenologic asupra unei asociaţii nitrofile nouǎ pentru România. Stud. Univ. BabeşBolyai, Ser. Biol. 1: 5-8.

Radke, G. J., 1980. System of ecologic and geographic landscape classification, shown in the central Europe region. Acta Bot. Acad. Sci. Hung. 26: 169-180.

Rostański, K.\& Gutte, P., 1971. Roślinność ruderalna miasta Wrocławia. Mater. Zakł. Fitosoc. Stos. Uniw. Warszaw. 27: $167-215$

Seybold, S. \& Müller, Th., 1972. Beitrag zur Kenntnis der Schwarznessel (Ballota nigra agg.) und ihre Vergesellschaftung. Veröff. Landesstelle Naturschutz Baden-Württemberg 40: $51-126$. 
Sissingh, G., 1950. Onkruid-associaties in Nederland. Thesis Wageningen. s'Gravenhage. $224 \mathrm{pp}$.

Smejkal, M., 1980. Komentovaný katalóg moravské flóry. Universita J. E. Purkynẻ, Brno. 301 pp.

Sneath, P. H. A. \& Sokal, R. R., 1973. Numerical Taxonomy. W. H. Freeman \& Co., San Francisco. 573 pp.

Soó, R., 1964. A magyar flóra és vegetáció rendszertani-növényföldrajzi kézikönyve. I. Akadémiai kiadó, Budapest. 589 pp.

Soó, R., 1971. Aufzählung der Assoziationen der ungarischen Vegetation nach den neueren zönosystematisch-nomenklatorischen Ergebnissen. Acta Bot. Acad. Sci. Hung. 17: $127-179$

Sowa, R., 1971. Flora i zbiorowiska ruderalne na obszarze województwa łódzkiego ze szczególnym uwzględnieniem miast i miasteczek. Universitet Łódzki, Lódz. 282 pp.

Tutin, T. G. et al. (eds.), 1964-1980. Flora Europaea. Vols. 1-5. University Press, Cambridge. 464, 455, 370, 505 \& 452 pp.

Ubrizsy, G., 1955. Magyarország ruderalis gyomnövénytársulásai II. Ökológiai és szukcessziö-tanulmányok. Növénytermelés 4 : $109-126$.
Ullmann, I., 1977. Die Vegetation des südlichen Maindreiecks. Hoppea 36: 5-190.

Werger, M. J. A. \& Gils. H. van, 1976. Phytosociological classification in chorological borderline areas. J. Biogeogr. 3: $49-54$.

Westhoff, V., Dijk, J. W. \& Passchier, H., 1946. Overzicht der Plantengemeenschappen in Nederland. 2nd ed. Uitg. K.N.N.V. \& N.J.N., Amsterdam.

Westhoff, V.\& Held, A. J. den, 1975. Planten-Gemeenschappen in Nederland. 2nd ed. W. J. Thieme \& Cie, Zutphen. 324 pp.

Westhoff, V. \& Maarel, E. van der, 1978. The Braun-Blanquet approach. In: R. Whittaker (ed.). Classification of Plant Communities, 2nd ed., pp. 287-399. Junk, The Hague.

Wishart, D., 1978. Clustan 1C. User Manual. St. Andrews Computing Centre, London. 175 pp.

Accepted 19.1.1984.

\section{Appendix}

\section{Columns in the synoptic table}

Table 1. Berteroetum incanae and Centaureo diffusae-Berteroetum in Europe.

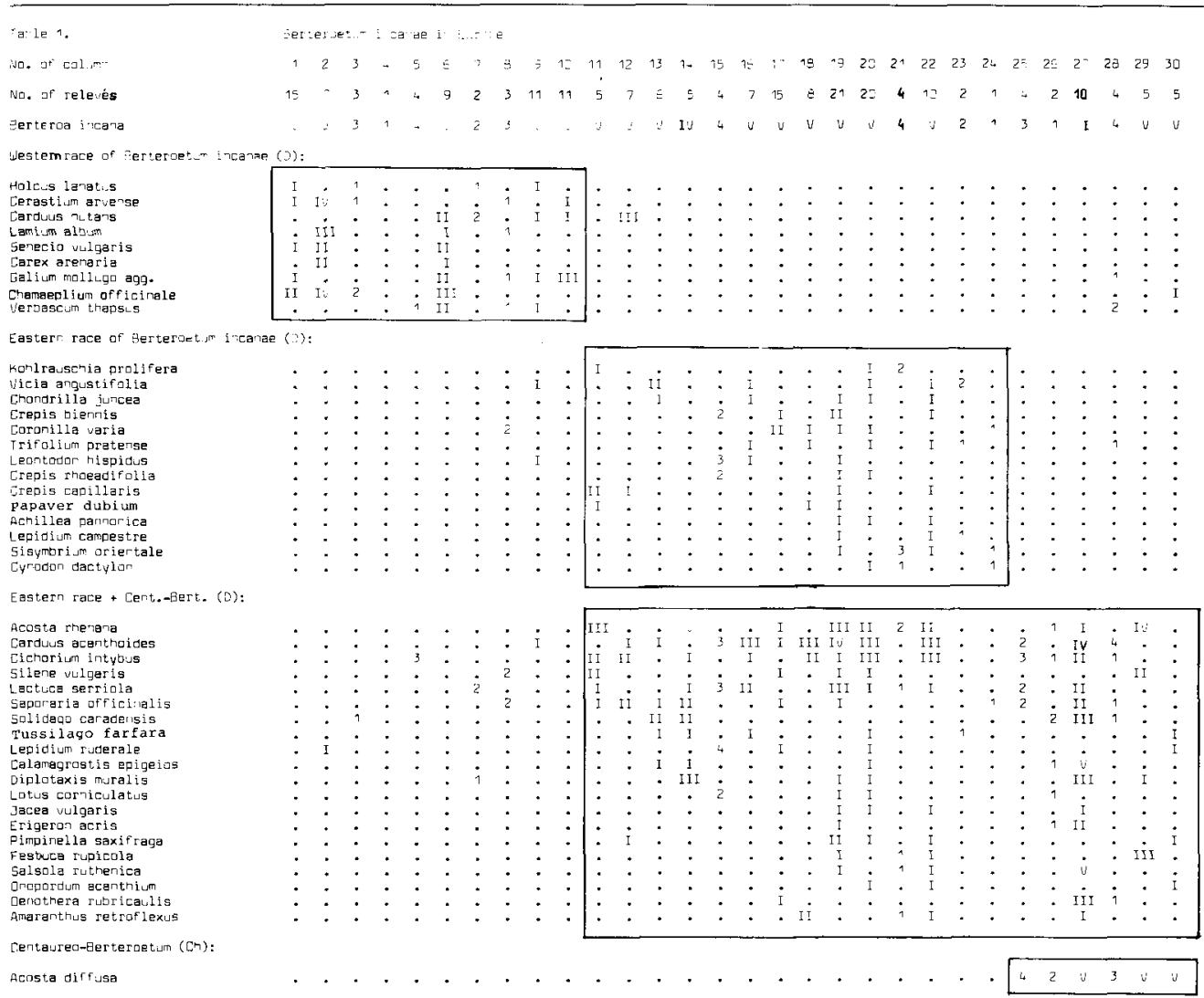




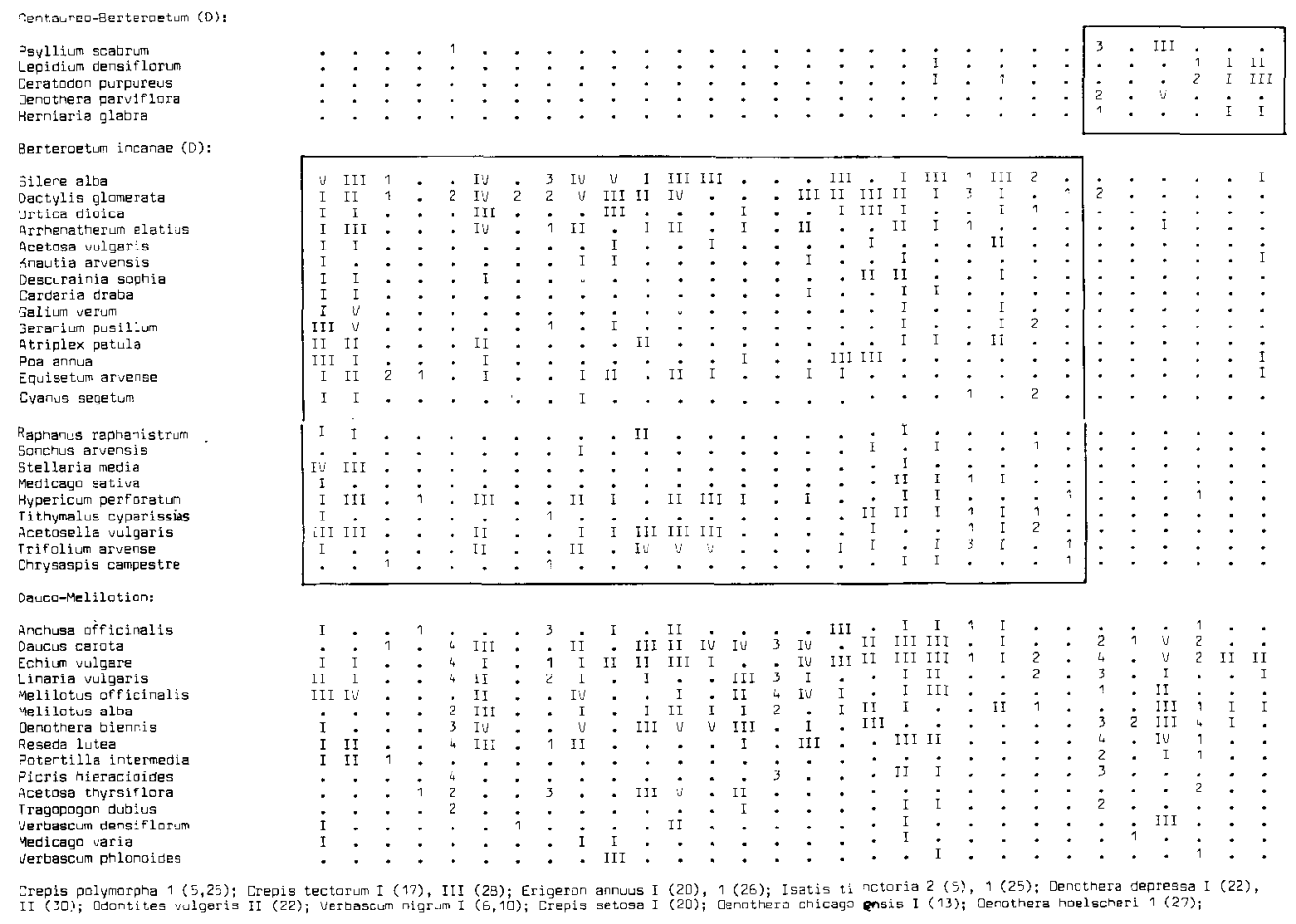

Onopordion acentrii:

Artemisia absirithium Reseda luteola

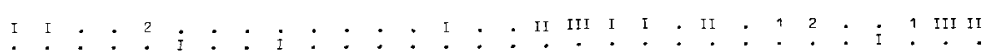

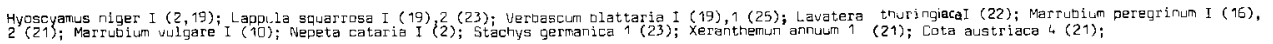

Artemisietea vulgaris:

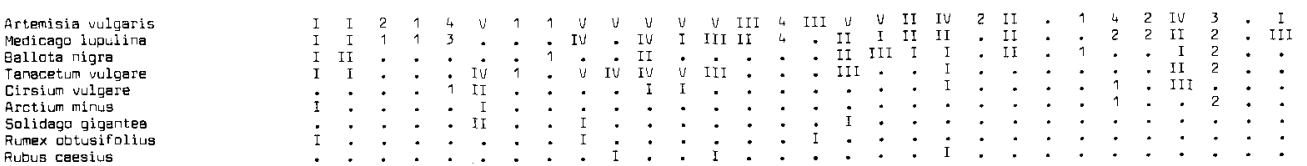

Carduus crispus II (9), I (19); Lapsana commuria I (19), 1 (20); Anthriseus syluestris I (19); Aretium lappe I (17); Arnaracia rusticana I (13); (alyste-

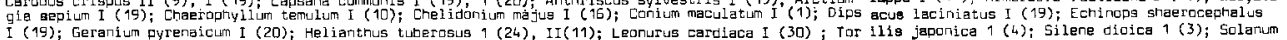
I (19); Geranium pyrenaicum I (20); Helianthus tuber
dulcamiata I (14); Malva sylvestris $2(7), 1(24) ;$
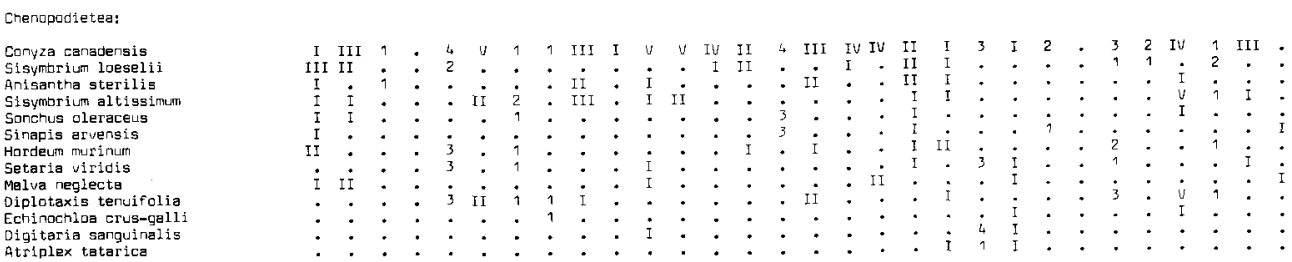

Amaranthus albus 1 (22,20); Ambrosia artemisiifolia I (1,2); Atriplex acuminata $1(8,25)$; bunias orient al is I (7), 5 (23); Erucastrum gallicum 3 (4), 1 (25);

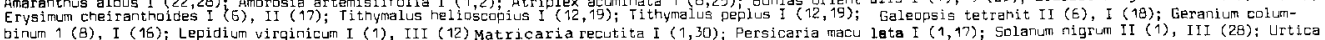

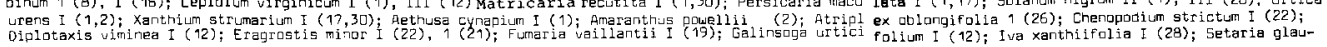
oa III (22); Partulaca diaracea $1(21) ;$

Sercalieter:

Apera spica-venti
Anthemis arvensis Papaver rnaeas

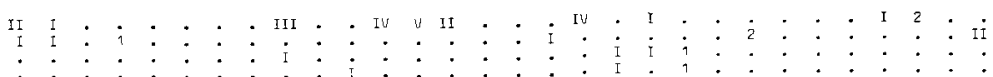

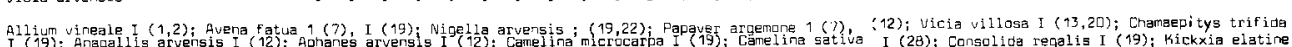

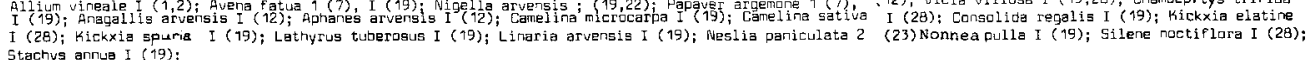


Agropyretea repertis:

Paa campressa

Carex hirta

Tithymalus es

Plantaginetea majoris:

Polygonum auic lare вgg.

Plantaga major
Rumex erispus

Sedrzonerdites autumnalis

Agrostis stulonifera

Ootentilla reptans

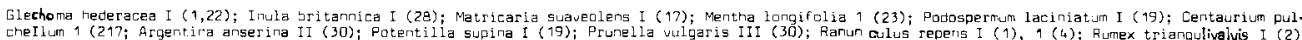

Convolvula-Chenandiea:

Elytrigia repens

Chenopodium album

Capsella bursa-pastaris

Matricaria perforata

Cirsicm arvense

Molinio-Arrhenatheretea

Achillea millefolium

Plantago lanceolata

Trifolium repens
Toraxacum sect. ULigari

Lolium perenne

Pog pratensis

Pastinaca sativa

Agrostig tenuis

Festuca rubra
Hypochoeris radiceta

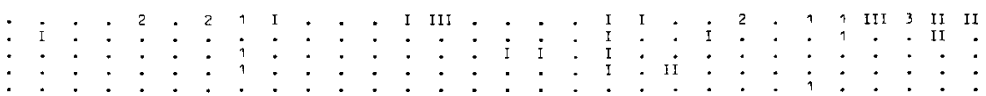

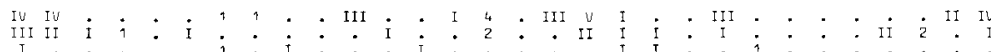

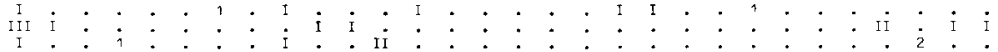

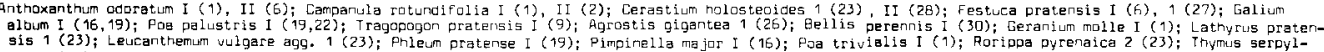
sis 1 (23); Leucanthemlom vulgare agg. 1 (23); Phleum pratense I (19); Pimpineliz ma jas I (15); Poa trivialis I (9); Rortppa pyrenaica 2 (23); Thymus serpyllum I (22); veronica chamaedrys I (30); Uicia sepium I (22); Uicia craccaI 16,20 )

Festuco-Brametea:

Eryngium eampestre
Artemisia carnpestris

Poa angustifolia

Medicago falcata

Festuca duing

Salvia verticillata

Saluia nemorasa
Erysinum diffusum

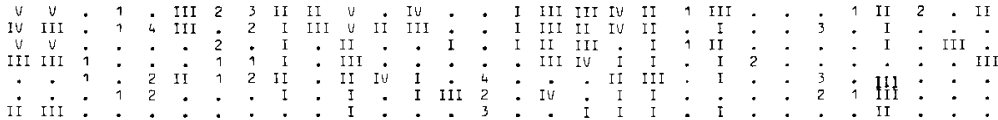
1 (27); Taraxacum sect. Erythrosperma I (1,2); Verbascum lychnitis $9(5,25)$; Achillea follina I (19), 2 (21); Asparagus dfficinalis I ( 9 ); Asperula cynanca trachyphylla I (19);

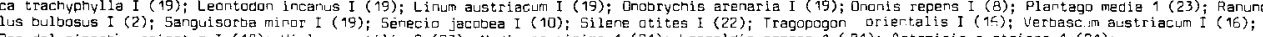
Pseudolysimachion spicatum I (18); Viala saxatilis 2 (23); Medicago minima 1(21); Leopoldia comasa 1 (21); Artemisia austriaca 1 (21);

Sedo-Scleranthetea:

Erodium cicutarium

Sedum acre

Eromus mollis

Anisentha tectorum

Potentil serpyliffol

Senecio vi scosus

Vicia hirsuta

Anthemis ruthenica

Eramus squarrosus

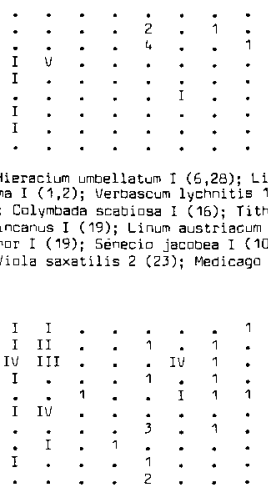

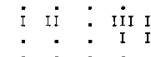
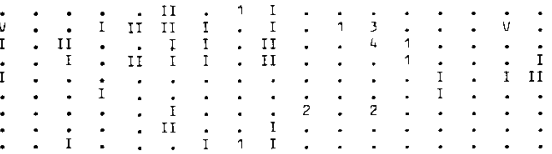

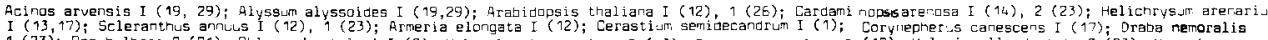
(23); Paa bulbosa 2 (21); Phleurn tertoloni I (2); Hylatelephi um maximum I ( 3 ); Jedum gexangulare I (12); valerianella dentata 2 (23); veronica arvensis

Dther species (Trifoliowageranietea, Thlaspieted rotundifolii, Rhamno-Prunetea, Luerco-Fagetea and others):

Epilobium angustifolium 1 (7), I (9); Linaria regens I (5), 1 (25); Rosa canina I (14, 19); Sambucus nigra I (1, 14); Agrimonia eupatoria I (21); Ailanthus altissima juv. I (20); Arctium sp. 1 (27); Aster sp. I (28); Avena sativa I (19); Eromus sp. I (19); Clema tis vitaba I (20); Clinagodium vulgare I (16);

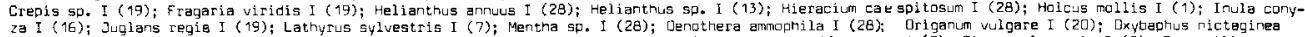

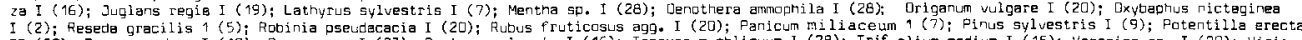

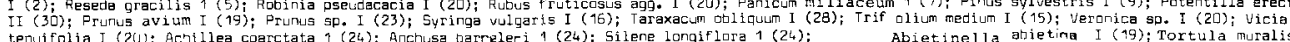

Eryostivta:

Musci indet.

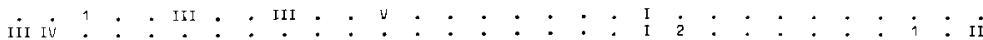

Brachythecium albicans I (2), 2 (27); Brachythecium so. I (1,22); Pohlia sp. II (1), III (2); Aloina rigida III (30); Barbula canvaluta I (30); Bryum

aespiticium 2 (27); Campylium chrysophyllum I (30); Hypnum vaucheri I (19); Rhacomitrium canescens I (1);

Berteroetum incanae, Galium mollugo race:

1. Sissingh (1950), The Netherlands, 15

2. Sissingh (1950), The Netherlands, 7

3. Runge (unpubl.), Westfalen (F.R.G.), 3

4. Westhoff (unpubl.), Molsbergen (Denmark),

5. Th. Müller (unpubl.), Ulm, Soflingen, Krs. Ludwigsburg (F.R.G.), 4 
6. Lienenbecker (1968, unpubl.), vicinity of Bielefeld (F.R.G.), 9

7. Hülbusch \& Kuhbier (1979), Bremen (F.R.G.), 2

8. Ullmann (1977), Maindreieck near Ochsenfurt (F.R.G.), 3

9. Brandes (1977, unpubl.), vicinity of Braunschweig (F.R.G.), 11

10. Passarge (1959), Brandenburg, Ost-Mecklenburg (G.D.R.), 11

Berteroetum incanae, Acosta rhenana race:

11. Nezadal (unpubl.), Rednitztal near Nürnberg (F.R.G.), 5

12. Brandes (unpubl.), Bamberg (F.R.G.), 6

13. Passarge (1964, unpubl.), Hagenow, Schwanenbeck-Alpenberge, Berling (G.D.R.), 7

14. Kunick (unpubl.), West Berlin (F.R.G.), 5

15. Grüll (1982), Brno (Czechoslovakia), 4

16. Forstner (unpubl.), Niederösterreich, Burgenland (Austria), 7

17. Kẹpczyński (1975), Bydgoszcz (Poland), 15

18. Czaplewska (1980), Aleksandrowie Kuj., Ciechocinek, Nieszawa, Wroclawek (Poland), 8

19. Mucina ( $198 \mathrm{lb}$, unpubl.), the western part of Slovakia (Czechoslovakia), 21

20. Jarolímek (unpubl.), Bratislava (Czechoslovakia), 20

21. Mucina (unpubl.), the southern part of the Podunajská Nízina Lowland (Czechoslovakia), 4

22. Mucina \& Zaliberová (unpubl.), the Východoslovenská Nižina Lowland (Czechoslovakia), 10

23. Pop \& Hodişan 1970, Valea Someşului Rece (Roumania), 2

24. Mucina (unpubl.), Melnik (Bulgaria), 1

Centaureo diffusae-Berteroetum:

25. Oberdorfer (1957), Karlsruhe, Mannheim (F.R.G.), 2

26. Th. Müller (unpubl.), Krs. Ludwigsburg (F.R.G.). 2

27. Kunick (unpubl.), West Berlin (F.R.G.), 2

28. Gutte (1966), vicinity of Leipzig (G.D.R.), 10

29. Rostański \& Gutte (1971), Wrocław (Poland), 4

30. Sowa (1971), Łódz, Tomaszów Mazowiecki (Poland), 5

31. Fijałkowski (1978), woj. Lubelskie (Poland), 5 